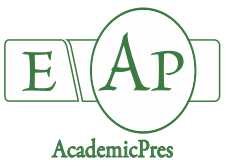

Perez-Leal R et al. (2020)

Notulae Botanicae Horti Agrobotanici Cluj-Napoca 48(1):426-435

DOI: $10.15835 /$ nbha48111505

Research Article

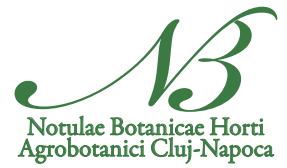

\title{
Phytotoxic and dissuasive activity of Chihuahua desert plants
}

\author{
Ramona PEREZ-LEAL, Maribel TORRES-RAMOS, \\ Maria A. FLORES-CORDOVA*, Ana C. GONZALEZ-FRANCO, \\ Adriana HERNANDEZ-RODRIGUEZ, Juan M. SOTO-PARRA, \\ Loreto ROBLES-HERNANDEZ
}

\author{
Autonomous University Chibuahua, Faculty of Agro-Technological Sciences UACH, Chibuahua, \\ México; mariflor_556@hotmail.com ("correspondingauthor); rleal@uach.mx; mtr_vida@hotmail.com; conzalez@uach.mx; \\ aernande@uach.mx; jmsotoparra@gmail.com; lrobles@uach.mx
}

\begin{abstract}
With the purpose of finding plant compounds with the potential use as herbicides and insecticides, a research was realized with the objective of evaluate the phytotoxic and dissuasive activity of four Chihuahua desert plants. The phytotoxic activity evaluation was tested on Lactuca sativa and Lolium perenne, while the dissuasive activity was realized on three species of phytophagous insects: Myzus persicae, Rhopalosiphum padi and Spodoptera littoralis. Raw extracts were used, the solvents hexane, methanol and ethanol of different plants' organs (root, steam, leaf and flower) of four species: Fouquieria splendens (ocotillo), Larrea tridentate (governor), Astragalus mollissimus (wild grass) and Pachycereus pecten-aboriginum (echo), by the establishment of in vitro bioassays at a concentration of $10 \mathrm{mg} / \mathrm{ml}$ extract/solvent. In the toxicity bioassay, the percentage of germination, root and leaf length were measured. The results showed that the leaf extract of L. tridentata had phytotoxic activity for L. sativa, while for $L$.perenne the phytotoxicity was observed within the ocotillo, governor and echo extracts. In the dissuasive bioassay, each treatment had 20 repetitions with 10 adult insects per repetition. The methanolic extracts of $F$. splendens leaf and root, ethanolic extract of $A$. mollisimus sheet and the ethanolic extract of $P$.pecten-aboriginum stems showed moderate dissuasive response of feeding against $M$. persicae, presenting a settlement inhibition index of 53.53, 54.35, 60.00 and $48.84 \%$ respectively. Nevertheless, the results indicated that none of the 10 extracts tested on S. littoralis showed significant dissuasive properties for this Lepidoptera, while for $R$. padi all the tested extracts presented dissuasive properties. The treatments of the four vegetable species evaluated showed defensive or dissuasive properties of moderate to strong feeding against the insects $M$. persicae and $R$. padi, presenting interesting potential for being used as insecticides, while the tested extracts that presented phytotoxicity for both lettuce and ryegrass present possibilities for the realization of herbicides.
\end{abstract}

Keywords: antifeedant; natural insecticides; phytotoxicity; vegetable extracts 


\section{Introduction}

The botanical compounds constitute an old alternative for the control of agricultural pests (Perez, 2012). It is currently known that secondary metabolites have an important role in the defensive mechanism of plants. Therefore, in recent years, the use of such components as a source of biopesticide preparation has been returning (Celis et al., 2008), since these metabolites can be isolated and used in agriculture as an alternative for the integrated control of pests and diseases (Emilia et al., 2013). Synthetic insecticides have been the most used elements for the control of harmful organisms, causing serious consequences to the ecosystem and generating the development of resistance in pests that were intended to be controlled (Perez et al., 2013). The aforementioned, together with the recognition of the biological properties of numerous plant species, has led to the search of new natural compounds extracted from plants with the potential use as insecticides and herbicides with less impact on the environment (Rodriguez and Barreto, 2015). Currently there is a certain number of plant-based insecticides that are being marketed worldwide, such as azadirachtin, rotenone, nicotine and sabadilla (Mendoza et al., 2007, Perez, 2012). Likewise, botanical pesticides include nematicides that inhibit germination, fungicides and new herbicides (Nava-Perez et al., 2012).

The majority of plant species have some type of phytochemical study. However, there are many aspects that remain empirical, which is a limitation to know the bioactive components and their diverse applications in the agronomic field (Celis, 2008). Monreal-Garcia et al. (2014) evaluated phenolic compounds of foliar tissues of extracts of Fouqueiria splendens, whereas they mention that the presence of these compounds can serve as an indicator of the attack of some pathogenic agent, since these are secreted as a defense mechanism. Likewise, Salas (2013) reports a work done by Fimbres and Garcia (1998) in a combination of extracts of $P$. pecten-aboriginum and Lphocerus schottii reporting bactericidal and antifungal activity. Flores et al. (2015) evaluated the allelopathic activity of Astragalus mollissimus in Lactuca vitreous seeds, Halepense sorghum, Lolium multiflorum, Arundo donax and Medicago sativa detecting allelopathic activity as a possible natural herbicide, with respect to $L$. tridentate. There are scientific investigations that mention the biological properties that this shrub possesses; it has been reported that its components have antifungal, antibacterial, nematicidal, phytotoxic and insect repellent effects (Moreno-Limon et al., 2011; Peñuelas-Rubio et al., 2017), as well as being used for its medicinal properties (Lambert, 2004).

Therefore, the objective of the present work was to evaluate the phytotoxic and dissuasive activity of the Chihuahua desert plants Fouquieria splendens (ocotillo), Larrea tridentata (governor), Astragalus mollissimus (wild grass) and Pachycereus pecten-aboriginum (echo), on Lactuca sativa and Lolium perenne and the dissuasive effect of feeding on three phytophagous insects of worldwide economic importance, Myzus persicae, Rhopalosiphum padi and Spodoptera littoralis, using raw extracts obtained of the four plant species mentioned.

\section{Materials and Methods}

\section{Preparation of raw extracts}

The collected plant material (root, stem, leaf and flower) was washed and dried at room temperature, after which was cut and placed in paper bags, dried in a Tork-type stove (Felisa) for five days at $40{ }^{\circ} \mathrm{C}$ and milled to obtain a fine powder. For the maceration, the solvents hexane, methanol and ethanol were separately used for each plant organ for 48 hours. The extracts were concentrated under reduced pressure. The extracts were stored at $-22^{\circ} \mathrm{C}$; the solutions of each extract to be tested were prepared in the bioassays, at a concentration of $10 \mathrm{mg} \mathrm{ml}^{-1}$ extract/solvent. Juglone was used as a positive control and pure methanol as a negative control (Table 1). 


\section{Phytotoxic bioassay}

The bioassay was carried out in vegetable cultivation chambers with a photoperiod of 16:8 (L:O) at 23-24 ${ }^{\circ} \mathrm{C}$, according to the methodology proposed by Moiteiro et al. (2006). The seeds used were from Lactuca sativa ‘Carrasco' variety (certified, Arnedo, La Rioja) and Lolium perenne variety 'Nui', lot 3881157. Variables regarding the germination percentage and radicle length were evaluated for the two species, while, in addition, leaf length was measured for L.perenne.

Table 1. Evaluated treatments for phytotoxic bioassay using Chihuahua desert species

\begin{tabular}{|c|c|c|c|}
\hline Plant species & Common name & Organ and solvent & Treatment \\
\hline Fouquieria splendens & Ocotillo & $\begin{array}{l}\text { Hexane sheet } \\
\text { Methanol sheet } \\
\text { Methanol root }\end{array}$ & $\begin{array}{l}\text { ohh } \\
\text { ohm } \\
\text { orm }\end{array}$ \\
\hline Larrea tridentata & Governor & $\begin{array}{c}\text { Ethanol root } \\
\text { Ethanol sheet } \\
\text { Methanol sheet }\end{array}$ & $\begin{array}{l}\text { gre } \\
\text { ghe } \\
\text { ghm }\end{array}$ \\
\hline Astragallus mollissimus & Crazy grass & $\begin{array}{c}\text { Ethanol flower } \\
\text { Ethanol sheet }\end{array}$ & $\begin{array}{l}\text { hlfe } \\
\text { hlhe }\end{array}$ \\
\hline Paquicereus pecten-aboriginum & Echo & $\begin{array}{l}\text { Stem } 10 \text { r. ethanol } \\
\text { Stem } 12 \text { r. ethanol }\end{array}$ & $\begin{array}{l}\text { ht10e } \\
\text { ht } 12 \mathrm{e}\end{array}$ \\
\hline Control & $\begin{array}{l}\text { Positive control } \\
\text { Negative control }\end{array}$ & $\begin{array}{l}\text { Juglone } \\
\text { Methanol }\end{array}$ & $\begin{array}{l}\text { tju } \\
\text { tdi }\end{array}$ \\
\hline
\end{tabular}

\section{Establishment of the bioassay on L. sativa and L. perenne}

The seeds were hydrated for 12 hours before the test. Later, a dose of $20 \mu \mathrm{l}$ of each treatment was added to $2.5 \mathrm{~cm}$ diameter filter paper discs; once dried, they were placed in plastic boxes and 10 seeds per disc were placed and hydrated with $500 \mu \mathrm{l}$ of distilled water; the boxes were sealed with parafilm and placed in the chamber for germination. The negative control (only with solvent) was prepared in the same manner and with the same dose, plus water; the control with juglone used as reference for phytotoxicity, was prepared likewise, in a concentration of $5 \mathrm{mg} \mathrm{ml}^{-1}$ (juglone/acetone) (Kocacaliskan, 2001). The readings were carried out every 24 hours, for six days ( 144 hours), counting the number of germinated seeds. At the end of the test, the root and leaf length were measured using the program Image J version 1.37 r. 2006 (Rodilla et al., 2008). The effect of the treatments was verified by an ANOVA analysis of the results obtained, whereas the design used was a completely randomized factorial arrangement with 4 repetitions per treatment and comparison of Tukey means with an $\alpha=0.05$.

\section{Dissuasive bioassay of feeding of phytophagous insects}

The species used (Myzus persicae, Rhopalosiphum padi) were raised in secondary host plants Capsicum annum and Hordeum vulgare, while Spodoptera littoralis was fed a general diet for noctuid's, in chambers heated at a temperature of $22 \pm 1{ }^{\circ} \mathrm{C}$, with a relative humidity of $60-70 \%$ and photoperiod 16:8 (L:O) (Rodilla et al., 2008; Burgueño-Tapia et al., 2008).

\section{Establishment of the bioassay on S. littoralis}

The dissuasive effects of the feeding of the evaluated extracts were carried out through tests with possibility of choice where larvae of the fifth and sixth stage (L5, L6) of S. littoralis were used. Each treatment had 5 repetitions, with completely random experimental design, which consisted of 5 Petri dishes with a layer of insect agar (2.5\%), with 4 holes with equivalent distances where discs of leaves of $C$. annuum of $1 \mathrm{~cm}^{2}$ were placed; in two discs, the extract to be tested was applied $(10 \mu \mathrm{l})$, while the other two discs served as controls where only the solvent was applied; two larvae of S. littoralis were deposited in each box (Gonzalez-Coloma et 
al., 1995, 1996 and 2008). Once 75\% of the surface of the discs was consumed (control or treatment), the larvae were removed. The unconsumed foliar surfaces were measured with the image analysis program Image J. 1.37 r, 2006 (Rodilla et al., 2008). The consumption index (FI) was calculated: FI $=1-(\mathrm{T} / \mathrm{C}) \times 100 \%$, where $\mathrm{T}$ : Consumption of the treatment, $\mathrm{C}$ : Consumption of the control or witness. It was considered that if $\mathrm{FI} \geq 75$, it corresponds to a highly active extract, while $50<\mathrm{FI}<75$ ) indicate a moderately active extract (Gonzalez-Coloma et al., 2008; Rodilla et al., 2008).

\section{Establishment of the bioassay for M. persicae and R. padi}

Each treatment consisted of 20 repetitions with 10 adult insects per repetition. Plastic boxes of $3 \times 3 \times$ $1.5 \mathrm{~cm}$, covered and ventilated, in an inverted position, with a surface of $2.5 \%$ insect agar were used. For $M$. persicae assay, discs of $C$. annum leaves of $1 \mathrm{~cm}^{2}$ in diameter were prepared, while for $R$.padi two fragments of $H$. vulgare foliole, with a surface area of $2 \mathrm{~cm}^{2}$, were used (Gutierrez et al., 1997), whereas half disc or foliole fragment was treated with the solution of the extract to be tested, with a dose of $10 \mu \mathrm{l}$ in a concentration of 10 $\mathrm{mg} \mathrm{ml}^{-1}$ (extract/solvent), and the other half of the disc or fragment was treated with pure solvent with the same dose as the treatment (Reina et al., 2001). Each treatment was subsequently incubated in chambers under the same climatic conditions mentioned for the maintenance of these insects, by a completely random design. After 24 hours, the aphids were counted in the treatment and in the control, calculating the settlement inhibition index $(\mathrm{SI})$ for each treatment: SI $=[1-(\% \mathrm{~T} / \% \mathrm{C})] \times 100$, where $\mathrm{T}$ : percentage of aphids on the treated surface, \% C: percentage of aphids on the surface of the sample or control. It was considered that a SI $\geq 60$ represents a highly active extract and $45<$ SI $<60$ is considered as a moderately active extract (Gonzalez-Coloma et al., 2008; Rodilla et al., 2008).

\section{Results and Discussion}

\section{Phytotoxic effect on Lactuca sativa}

In regard with the inhibition of germination of $L$. sativa seeds, of the 12 treatments tested only the ethanolic extract of $L$. tridentata leaf showed germination delay compared to the control, observing $45 \%$ germination after 24 hours, reaching $92 \%$ after 120 hours and $95 \%$ after 144 hours (Figure 1). In the rest of the treatments there were no significant differences in this variable. Regarding the radical length, only two of the evaluated extracts showed activity, significantly inhibiting the growth of the root (Figure 2). The shortest length, in addition to causing deformations, was obtained with the ethanolic treatment of $L$. tridentata leaf. Reported results from similar studies mention that researchers found inhibition of radicular and hypocotyl growth of $L$. sativa with extracts of NDGA (Nordihydroguaiaretic acid), the main component of $L$. tridentata leaf (Delgado et al., 2014). On the other hand, the hereby results differ from those reported by Lira-Saldivar et al. (2008) who mentioned that when testing extracts of said species, they showed a bio stimulating effect on the germination and growth of $L$. sativa. In the present study, the second treatment that showed phytotoxic activity in root growth was the methanolic extract of ocotillo root, unlike the percentage of germination where it showed no inhibition. At the moment, there are no scientific publications that mention phytotoxic properties of F. splendens (ocotillo). 


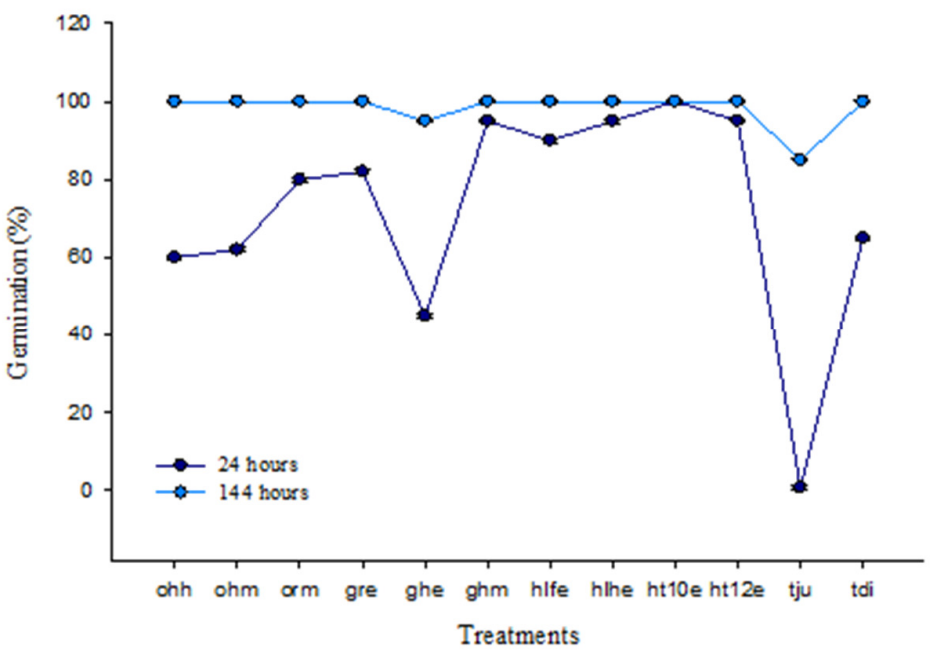

Figure 1. Phytotoxic effects of the applied treatments on germination percentage of L. sativa at 24 and 144 hours

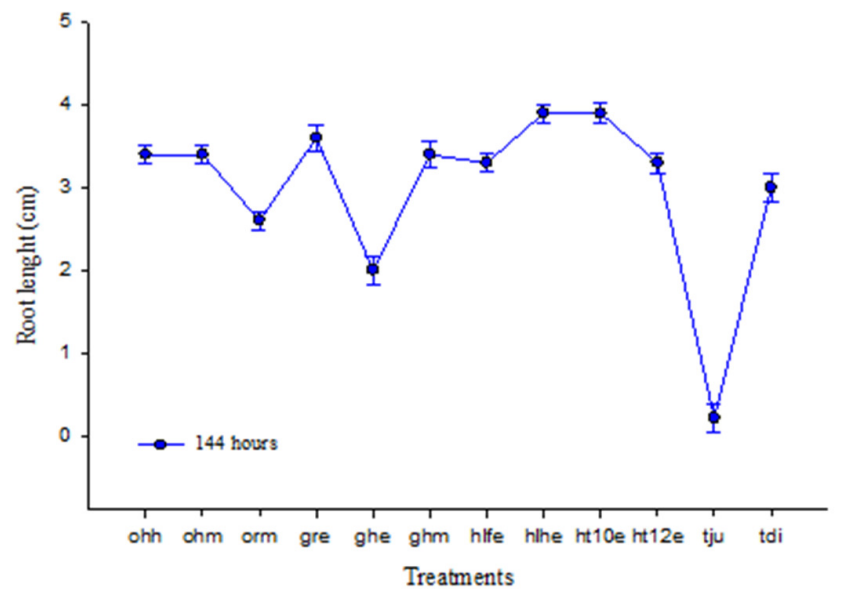

Figure 2. Phytotoxic effects of the applied treatments on the seedling root length of L. sativa at 144 hours

\section{Phytotoxic effect on Lolium perenne}

The germination percentage for L. perenne species was evaluated (Figure 3). The treatments with the methanol extract of the ocotillo and governor leaves, as well as the ethanolic extract of the stem of 10 echo ribs, showed significant phytotoxic activity at the end of the study (144 hours). Regarding the inhibition of root growth of L. perenne seedlings, the extracts that showed inhibition were: methanolic from the root of $F$. splendens and stem ethanolic from 10 ribs of $P$. pecten-aboriginum (Figure 4). For leaf length, none of the treatments showed significant inhibition of growth except for the methanolic extract of ocotillo root,and the leaf ethanolic extract of L. tridentata, which showed stimulating effects on the leaf length. Zarate-Hernandez et al. (2008) found phytotoxic effects on germination, leaf and root length in L.perenne when testing aqueous extracts of Calia secundiflora leaf at 5\% concentration. Young and Bush (2009) reported significant inhibition in germination of grass Bouteloua curtipendula monocotyledonea belonging to the family Poaceae, due to the action of leaf extracts of Juniperus ashei Buchh. 
Dissuasive bioassays of the tested insects feeding

Dissuasive effect of feeding of Spodoptera littoralis

The results obtained in this bioassay indicated that none of the 10 extracts tested on S. littoralis showed significant dissuasive properties for this lepidoptera (Table 2). Likewise, no scientific evidence of these plant extracts or the dissuasive properties of this insect have been found in other works previously done. For example, Gonzalez-Coloma et al. (2006) reported the low effect (FI of 33\%) of essential oils extracted from leaves and flowers of Lavandula luisieri against $S$. littoralis. In 2008, the same author and collaborators mentioned that after evaluating diterpene neo-clerodane isolated from parts of the species Linaria saxactilis, with a dose of $50 \mathrm{~g} / \mathrm{cm}^{2}$, the results showed no toxic effect for $S$. littoralis. However, there are other works carried out with $S$. littoralis and similar species that show contrary results, such as Rodilla et al. (2008) report that noted the essential oils extracted from L. novocanariensis showed a moderate effect of 55\% of FI against S. littoralis.

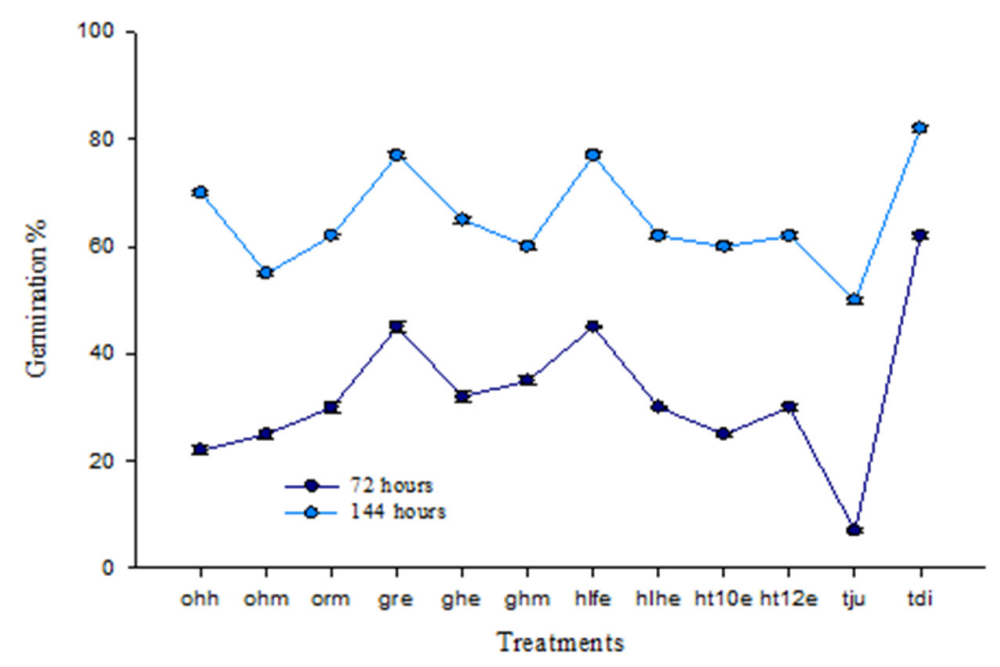

Figure 3. Phytotoxic effects of the applied treatments on germination percentage of $L$.perenne at 72 and 144 hours

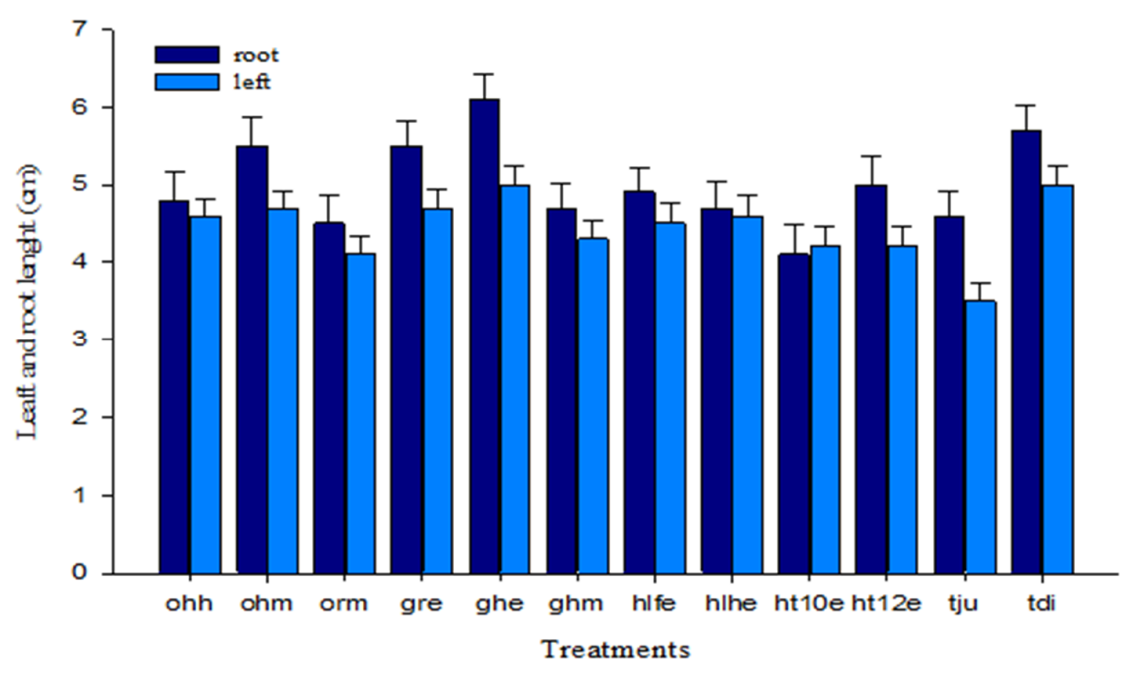

Figure 4. Phytotoxic effects of the applied treatments on the root and leaf length of $L$. perenne at 144 hours 
Table 2. Dissuasive activity of four plant species extracts against Spodopera littoralis, Myzus persicae and Rophalosiphumpadi

\begin{tabular}{|c|c|c|c|c|c|c|c|c|c|}
\hline \multicolumn{2}{|c|}{ S. littoralis } & \multicolumn{5}{|c|}{ M. persicae } & \multicolumn{4}{c|}{ R.padi } \\
\hline Treat. & \% FI & Treat. & \% C & \% T & \% SI & Treat. & \% C & $\%$ T & \% SI \\
\hline ohh & 22.13 & ohm & 70 & 29 & 55.53 & orm & 78 & 21 & 70.30 \\
\hline ohm & 11.70 & orm & 69 & 30 & 54.35 & ghe & 72 & 27 & 54.80 \\
\hline orm & 12.25 & ghe & 31 & 68 & 6.31 & ht10e & 71 & 28 & 54.50 \\
\hline gre & 28.14 & hlfe & 59 & 40 & 31.33 & ht12e & 82 & 13 & 76.10 \\
\hline ghe & 12.72 & hlhe & 72 & 28 & 60.00 & & & & \\
\hline ghm & 20.83 & ht10e & 62 & 38 & 38.60 & & & & \\
\hline hlfe & 8.0 & ht12e & 68 & 31 & 48.84 & & & & \\
\hline hlhe & 12.24 & & & & & & & & \\
\hline ht10e & 40.93 & & & & & & & & \\
\hline ht10e & 46.59 & & & & & & & & \\
\hline
\end{tabular}

Treat $=$ Treatment; $\% \mathrm{FI}=$ dissuasive efficiency of treatment on the feeding; $\% \mathrm{SI}=$ inhibition of aphid settling; \% $\mathrm{T}$ $=$ percentage of aphids on the treatment surface; $\% \mathrm{C}=$ percentage of aphids on the control surface or control

\section{Dissuasive effect of feeding of Myzus persicae}

As shown in Table 2, the methanolic extracts of leaf and root of Fouquieria splendens, ethanolic extract of Astragalus mollisimus sheet and the ethanolic extract of stem of 12 ribs of $P$. pecten-aboriginum showed moderate dissuasive response of feeding against Myzus persicae, presenting a settlement inhibition index of $53.53,54.35,60.00$ and $48.84 \%$ respectively, unlike the other extracts tested, with low rates of settlement inhibition, below $40 \%$. In similar works, defensive properties of other plant species were sought against this species of aphid or similar species were noted. It has been found that there was dissuasive activity in $M$. persicae when evaluating neo-clerodane diterpenes of the plant species Linaria saxactilis, with a dose of 50 $\mathrm{g} / \mathrm{cm}^{2}$ (Gonzalez-Coloma et al., 2008). Likewise, Ricci et al. (2006) reported that the essential oils of lemongrass possess a repellent activity between 65 and 80\% against Russian aphid (Diuraphis noxia Kurdj). Comparing with the results of the hereby bioassay, it can be concluded that the proven concentration of 10 $\mathrm{mg} \mathrm{ml}^{-1}$ of the raw extracts mentioned have potential as a dissuasive of the feeding for M.persicae, taking into account that other works have used isolated and identified substances, unlike the raw extracts that were used in the current work.

\section{Dissuasive effect offeeding of Rophalosiphum padi}

All the tested extracts showed dissuasive activity against $R$. padi. It was observed that the methanol extract of the root of F. splendens and the ethanolic extract of the stem of 12 ribs of $P$. pecten-aboriginum showed a higher inhibition activity, with settlement percentages of $70.3 \%$ and $76.1 \%$ (Table 2). The ethanol extracts of $L$. tridentata leaf and the ethanolic extract of the stem of 10 ribs of $P$. pecten aboriginum showed moderate inhibition activity, with settlement percentages of $54.8 \%$ and $54.5 \%$. There is evidence of similar research carried out with other plant species on this aphid. Such as the works of Mazoir et al. (2008), which mention the strong dissociative effect against this insect of the polygodial derivatives obtained from two species of the Euphorbiaceae family with an SI up to 98\%. Moreno-Osorio et al. (2008) tested polygodial derivatives of the raw hexanic extract of bark from Drimys winteri, finding $98 \%$ of SI for the aphid R.padi. More recently, it was reported that Lycium centroides leaf extract presented dissuasive activity against $R$. padi of $52 \%$ of SI (Castillo et al., 2009). 


\section{Conclusions}

The ethanolic leaf extract of Larrea tridentata had phytotoxic properties on the root growth of the $L$. sativa species. The extracts of the ocotillo, governor and echo of 10 ribs species showed significant phytotoxicity in germination of L. perenne, as well as extracts of ocotillo and echo which inhibited the root length, while the foliar growth was affected by the phytotoxic inhibition of the methanolic extract of ocotillo root. The treatments of the four vegetable species evaluated showed defensive or dissuasive properties of moderate to strong feeding against the insects $M$. persicae and $R$. padi, presenting interesting potential in regard with future possibilities for the realization of insecticides. The tested extracts that presented phytotoxicity for both lettuce and ryegrass present possibilities for the realization of herbicides. It is necessary for the elucidation and identification of the compounds responsible for the phytotoxic and dissuasive activity of the feeding of said treatments to be further reached, since those evaluated in the present work were raw extracts under in vitro conditions; respective tests under greenhouse and field conditions are to be followed.

\section{Acknowledgements}

This research received no specific grant from any funding agency in the public, commercial, or not-forprofit sectors.

\section{Conflict of Interests}

The authors declare that there are no conflicts of interest related to this article.

\section{References}

Arias S, Terrazas T (2001). Variación en la anatomía de la madera de Pachycereus pecten-aboriginum (Cactácea) [Wood anatomy variation of Pachycereus pecten-aboriginum (Cactaceae)]. Serie Botánica 72(2):157-169.

Burgueño-Tapia E, Castillo L, González-Coloma A, Joseph-Natan P (2008). Antifeedant and phytotoxic activity of the sesquiterpene p-Benzoquinone perezone and some of its derivatives. Journal of Chemical Ecology 34(6):776-771.

Castillo L, González-Coloma A, González A, Díaz M, Santos E, Alonso-Paz E, ... Rossini C (2009). Screening of Uruguayan plants for dissuasive activity against insects. Industrial Crops and Products 29(1):235-240.

Celis A, Mendoza C, Pachón M, Cardona J, Delgada LE (2008). Plant extracts used as biocontrol with emphasis on Piperaceae family: a review. Agronomía Colombiana 26(1):97-106.

Chitwood DJ (2002). Phytochemical based spara strategias nematode control. Phytopathology 40:221-249.

Delgado RM, Guzman MK, Flores TE, Márquez D, Corral AA, Santana CLE, Romero GJ (2014). Caracteización y capacidad de adsorción de la especie vegetal Larrea tridentata como adsorbente de color [Characterization and adsorption capacity of the plant species Larrea tridentata as a color adsorbent]. Culcyt 54(1):208-224.

Flores-Córdova MA, Sánchez ChE, Pérez LR (2015). Potencial alelopático de extractos foliares de Astragalus mollissimus Torr. sobre la germinación in vitro de semillas de maleza [Allelopathic potential of leaf extracts from Astragalus mollissimus Torr. on in vitro germination of weed seeds]. Revista Mexicana de Ciencias Agricolas 6(5):1093-1103.

Gutiérrez C, Fereres A, Reina M, Cabrera RA, González-Coloma A (1997). Behavioral and sub-lethal effects of structurallyrelated lower terpenes on Myzus persicae. Journal of Chemical Ecology 23(6):1641-1650.

González-Coloma A, Gutiérrez C, Jos MC, Gordaliza M, De la Puente ML, San Feliciano A (2008). Structure and species dependent insecticidal effects of neo-clerodane diterpenes. Journal of Agriculture and Food Chemistry 48(8):36773671 . 
434

González-Coloma A, Martín-Benito D, Mohamed N, García-Vallejo MC, Soria AC (2006). Antifeedant effects and chemical composition of essential oils from different populations of Lavandula luisieri L. Biochemical Systematics and Ecology 34(8):609-616.

González-Coloma A, Terrero D, Perales A, Escoubas P, Fraga BM (1996). Insect antifeedant ryanodane diterpenes from Persea indica. Journal of Agriculture and Food Chemistry 44(1):296-300.

González-Coloma A, Cabrera R, Castañera P, Gutiérrez C (1995). Antifeedant and toxic effects of sesquiterpenes from Senecio Palmensis to Colorado potato beetle. Journal of Chemical Ecology 21:1255-1270.

Kocacaliskan I, Terzi I (2001). Allelopathic effects of walnut leaf extracts and juglone on seed germination and seedling growth. Journal Horticulture Science Biotechnology 76(4):436-440.

Kordaly S, Cakirb A, Aytas T, Meted E, Akcine A, Aydinb T, Kilic H (2008). Antifungal and herbicidal properties of essential oils and $n$-hexane extracts of Achillea gypsicola Hub-Mor. and Achillea biebersteinii Afan. (Asteraceae). Industrial Crops and Products. Science Direct 29(2-3):562-570.

Kruse M, Strandberg M, Strandberg B (2000). Ecological effects of allelopathic plants, a review. National Environmental Research Institute, Silkeborg, Denmark. NERI Technical Report No. 315, pp 66.

Lambert JD, Dorr RT, Timmermann BN (2004). Nordihydroguaiaretic acid: a review of its numerous and varied. Pharmaceutical Biology 42(2):149-158.

Lira-Saldivar RH, Díaz-Cortes Z, Sánchez-Rivera YE, Alemán-Granados FJ, Molina-Abadía GS, Facio-Parra F, ... Ruíz-Torres NA (2008). Promoción de la germinación de semillas y crecimiento de plántulas de cultivos básicos y hortícolas con extractos de Larrea tridentata [Promotion of seed germination and seedling growth of basic and horticultural crops with extracts of Larrea tridentate]. In: Ruiz-Torres NA, Lira-Saldivar RH (Eds). Tecnologías Sustentables en Semillas [Sustainable Seed Technologies]. Primera Ed, pp 184-197.

Moreno-Limón LN, González-Solís SM, Salcedo-Martínez ML, Cárdenas-Avila A, Perales-Ramírez A (2011). Efecto antifúngico de extractos de gobernadora (Larrea tridentata L.) sobre la inhibición in vitro de Aspergillus flavus y Penicillium sp. [Antifungal effect of gobernadora extracts (Larrea tridentata L.) on in vitro inhibiton of Aspergillus flavus and Penicillium sp.]. Polibotanica 32:193-205.

Moreno-Osorio L, Cortés M, Amstrong V, Bailen M, González-Coloma A (2008). Antifeedant activity of some polygodial derivatives. Zeitschrift fur Naturforschung 63(3-4):215-220.

Mazoir N, Ahmed B, Bailén M, Reina M, González-Coloma A (2008). Bioactive triterpene derivates from latex of two Euphorbia species. Phytochemistry 69:1328-1338.

Mendoza CB, Moreno MN, Weil M, Elango F (2007). Evaluación del efecto de extractos vegetales sobre el crecimiento in vitro Phytophthora palmivora (Butl). y Colletotrichum gloeosporioides (Penz.) Penz. \& Sacc. [Evaluation of the effect of plant extracts in vitro growth Phytophthora palmivora (Butl). and Colletotrichum gloeosporioides (Penz.) Penz. \& Sacc]. Tierra Tropicale 3(1):81-89.

Moiteiro C, Marcelo C, Mohamed NM, Bailén M, Martínez-Diaz R, González-Coloma A (2006). Bio-valorization of friendelane triterpenes derived from the cork processing industry by products. Journal of Agriculture and Food Chemistry 54(10):3566-3571.

Monrreal-García HM, Ávila-Reyes EA, Delgado-Alvarado EA, Cobaleda-Velasco M, Alanís-Bañuelos E, Medina-Medrano JR, ... Reyes-Martinez A (2014). Characterization of phenoles of Fouquieria splendens, Dodonaea viscosa and Physalis angulata by techniques chromatographics: preliminary. Vidsupra 6(1):1-6.

Nava-Perez E, García-Gutiérrez C, Camacho-Báez JR, Vazquez-Montoya EL (2012). Bioplaguicidas: una opción para el control biológico de plagas [Biopesticides: an option for biological pest control]. Ra Ximhai 8(3):17-29.

Reina M, González-Coloma A, Gutiérrez C, Cabrera R, Rodríguez ML, Fajardo V, Villarroel L (2001). Defensive chemistry of Senecio miser. Journal of Natural Products 64:6-11.

Rodriguez GDP, Barreto MAC (2013). Propiedades biológicas de Pedilanthus tithymaloides: una alternativa natural de tratamiento [Biological properties of Pedilanthus tithymaloides: a natural treatment alternative]. Revista Cienciactual 4:40-48.

Peñuelas-Rubio O, Arellano-Gil M, Verdugo-Fuentes AA, Chaparro-Encinas LA, Hernández-Rodríguez SE, MartínezCarrillo JL, Vargas-Arispuro IC (2017). Larrea tridentata extracts as an ecological strategy against Fusarium oxysporum radicis-lycopersici in tomato plants under greenhouse conditions. Patologia 35(3):360-376. 
Pérez LE (2012). Plaguicidas botánicos: una alternativa a tener en cuenta [Botanical pesticides: an alternative to consider]. Fitosanidad 16(1):51-59.

Pérez ME, Ruiz DM, Dchneider M, Sutino JC, Romanelli G (2013). La química verde como fuente de nuevos compuestos para el control de plagas agrícolas [Green chemistry as a source of novel compounds for agricultural pest control]. Revista Ciencia en Desarrollo 4(2):83-91.

Ricci M, Padín S, Ringuelet J, Kahan A (2006). Use of lemongrass (Cymbopogon citratus Stapf) essential oil as a repellent of Diuraphis noxia Kurdj. (Hemiptera: Aphididae) in wheat. Agricultura Técnica 66(3):256-263.

Rodilla JM, Tinoco MT, Morais CJ, Gimenez C, Cabrera R, Martín-Benito D, ... González-Coloma A (2008). Laurus novocanariensis essential oil: seasonal variation and valorization. Biochemical Systematics and Ecology 36(3):167-176.

Salas GAL (2013). Efecto del extracto de Jatropha dioica Sesse en el control de Fusarium oxysporum en tomate (Solanum lycopersicum L.) [Effect of Jatropha dioica Sesse extract on the control of Fusarium oxysporum in tomato (Solanum lycopersicum L.)]. Dissertation Thesis, Universidad Antonio Narro, pp 103.

Young GP, Bush JK (2009). Assessment of the allelopathic potential of Juniperus ashei on germination and growth of Bouteloua curtipendula, Journal of Chemical Ecology 35(1):7480.

Zarate-Hernández J, García-Mateos R, Zavala-Chávez F, Pérez LR, Soto-Hernández JM (2006). Fitotoxicidad de los extractos de Calia secundiflora (Ort.) Yakovlev [Phytotoxicity of Calia secundiflora (Ort.) Yakovlev extracts]. Revista Chapingo Serie Horticultura 12(2):197-202.

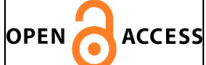

(c)
The journal offers free, immediate, and unrestricted access to peer-reviewed research and scholarly work. Users are allowed to read, download, copy, distribute, print, search, or link to the full texts of the articles, or use them for any other lawful purpose, without asking prior permission from the publisher or the author.

License - Articles published in Notulae Botanicae Horti Agrobotanici Cluj-Napoca are Open-Access, distributed under the terms and conditions of the Creative Commons Attribution (CC BY 4.0) License. (c) Articles by the authors; UASVM, Cluj-Napoca, Romania. The journal allows the author(s) to hold the copyright/to retain publishing rights without restriction. 